confirm political abuse of psychiatry, to ask the WPA to reconsider the constituent membership of the Chinese Society of Psychiatrists."

An additional paragraph ("(3) the College will commit itself to work with the Chinese Society of Psychiatrists to advance psychiatry and its practices in PRC to be ethically sound and evidencebased") was proposed by Dr E. Chiu, but was not seconded.

Following further discussion, an additional paragraph was proposed by Professor C. Katona and seconded by Professor C. Allwood: "(3) to work with the WPA to provide support for those Chinese psychiatrists who are committed to ethical and evidence-based practice." This was supported by an overwhelming majority.

The following amendment to paragraph (2) was proposed by Dr R. Brahma and seconded by Dr R. Lutchman: "if this visit and other evidence confirm widespread political abuse of psychiatry, to ask the WPA to reconsider the constituent membership of the Chinese Society of Psychiatrists". This amendment was defeated by a large majority.

A vote was then taken on the original resolution and the additional third paragraph: "Bearing in mind the available evidence that political dissidents in The People's Republic of China (PRC) are being systematically detained in psychiatric hospitals, we propose that the Royal College of Psychiatrists takes the following action: (1) to join with the WPA to arrange a fact-finding visit to the PRC; (2) if this visit and other evidence confirm political abuse of psychiatry, to ask the WPA to reconsider the constituent membership of the Chinese Society of Psychiatrists; (3) to work with the WPA to provide support for those Chinese psychiatrists who are committed to ethical and evidence-based practice." This was carried by an overwhelming majority.

\section{Election and introduction of Honorary Fellows}

The following were unanimously welcomed to the Honorary Fellowship.

\section{The Lord JohnThomas \\ Alderdice}

\section{(introduced by DrJ. Calvert)}

President, it is a great pleasure and honour for me to present for Honorary Fellowship of the Royal College of Psychiatrists a fellow Ulsterman, Dr John Thomas Alderdice, the Right Honourable Baron Alderdice of Knock.

John Thomas Alderdice was born in Northern Ireland on 28 March 1955, the eldest son of Reverend David and Mrs
Helena Alderdice. He was educated at primary schools in County Armagh and Belfast, and later Ballymena Academy, where he was Deputy Head Boy. In 1973 he read medicine at The Queen's University of Belfast, graduating MBBCh, BAO in 1978. In 1983 he became a Member of the Royal College of Psychiatrists (MRCPsych). This was followed by higher specialist training in psychoanalytic psychotherapy. In 1988 he was appointed by the Eastern Health and Social Services Board as Ireland's first consultant psychotherapist.

From 1991 to 1999 he was appointed an Honorary Lecturer (subsequently Senior Lecturer) in the Faculty of Medicine, at The Queen's University of Belfast teaching psychotherapy. In 1991 he was appointed the first Director of the Northern Ireland Institute of Human Relations, a position he held until October 1994. From 1993 to 1997 he served as Executive Medical Director of South and East Belfast Health \& Social Services Trust.

In 1997 he was elected a Fellow of the Royal College of Psychiatrists (FRCPsych). This was followed by his appointment in 1999 as Honorary Professor in the Faculty of Medicine, University of San Marcos, Lima. The following year he was appointed an Honorary Member of the Peruvian Psychiatric Association. Lord Alderdice joined the Alliance Party in Northern Ireland in 1978, and in October 1987 he was elected as Leader of the Alliance Party. This was followed by election to Belfast City Council in 1989 and reelection in 1993 with the largest vote of any candidate in Northern Ireland in that election.

From 1991 to 1998 Lord Alderdice led the Alliance Party delegation at the various inter-party and intergovernmental talks in Belfast, London and Dublin on the future of Northern Ireland. In 1994 he lead the Alliance Party into the Forum for Peace and Reconciliation, which was established by the Irish Government and took place at Dublin Castle. In political terms this was significant since the Alliance Party was the only non-nationalist party attending.

He had the privilege of becoming the first non-nationalist party leader to attend the White House for the annua St Patrick's Day celebrations in 1995. Frequent visits continue to cement the US and Northern Ireland relationships. Lord Alderdice was elected in 1996 to the new Northern Ireland Forum leading the Alliance Party delegation in the multi-party talks chaired by Senator George Mitchell.

John Alderdice was raised to the Peerage as Baron Alderdice of Knock in 1996. He took his seat in the House of Lords on 5 November of that year, being one of the youngest ever Life Peers. He plays a significant role in the Irish Peace Process, and was one of the key negotiators of the Belfast Agreement signed on Good Friday 1998. Lord Alderdice remains a committed internationalist. He was elected Treasurer and then, in 1999 Vice-President of the European Liberal Democratic and Reform Party. In October 2000 he was elected Deputy President of Liberal International, the world wide federation of some 90 Liberal political parties.

Following his election in 1998 as a member for Belfast East, in the new Northern Ireland Assembly established by the Irish Peace Process, he stood down as Alliance Leader after 11 years in that position. He was immediately appointed Speaker of the new Assembly. His contribution to peace has been recognised through a number of international awards, including Honorary Citizenship of the City of Baltimore (1991) and Honorary Fellowship of the Royal College of Physicians of Ireland (FRCPI, 1997). He was a recipient, jointly with the former President Bill Clinton and other signatories of the Belfast agreement, of the WA Harriman Award for Democracy (Washington, 1998) and, with Senator George Mitchell and other signatories of the Belfast agreement, the John F. Kennedy Profiles in Courage Award (1998). He also received the Silver Medal of the Congress of Peru (1999), and Medal of Honour of the College of Medicine of Peru (1999).

Outside psychiatry and politics Lord Alderdice has travelled widely through his involvement in national and international religious organisations. He has helped to found a number of Northern Ireland charities and professional organisations and is patron to a number of national health care charities.

Mr President, I have the honour to present for the distinguished award of Honorary Fellowship of the Royal College of Psychiatrists, Dr JohnThomas Alderdice, The Right Honourable, Baron Alderdice of Knock.

\section{ProfessorTom Arie \\ (introduced by DrA. Fairburn)}

Professor Tom Arie can truly be described as one of the founding fathers of old age psychiatry. He created an innovative service at Goodmayes Hospital in Essex from 1969 before moving on to the Chair of Health Care of the Elderly at Nottingham University in 1997. Throughout his entire career he has been such an enthusiastic champion of old age psychiatry that there are now literally dozens of consultants in old age psychiatry who were trained by him. Arguably this is the greatest testimony of all. 
Academically, he is the author of 236 papers or chapters and the editor of three books. His seminal publications shaped UK old age psychiatry services. He has been the member of eight editorial boards and invited to lecture throughout the world. He has been a visiting Professor to nine major universities.

At the Royal College of Psychiatrists he was the Chair of the then Section for the Psychiatry of Old Age and during his tenure the Section became increasingly politically active and influential in national policy making. Tom himself has been a major adviser to Government over many years.

He has also been active in the development of services in Europe and with the World Health Organization (WHO). He has been Vice-Chairman, then Chairman of the Medical Committee of the Royal Surgical Aids Society, a Patron of the Abbeyfield Society, a Governor of the Centre for Policy on Ageing and an honorary life member of both the European Association of Geriatric Psychiatry and the Society for Social Medicine. His contributions were nationally recognised by the honour of a $\mathrm{CBE}$ and he remains active in the Faculty for the Psychiatry of Old Age, even in retirement.

It is my very great pleasure, Mr President, ladies and gentlemen, to present Tom Arie for the Honorary Fellowship of the Royal College of Psychiatrists.

\section{Dr Gro Harlem Brundtland}

(introduced on Monday 9 July by Professor H. Ghodse)

Dr Brundtland is only able to attend this Meeting today and will therefore miss the AGM on Wednesday. It is therefore my great pleasure - and honour - to act as her Citator in presenting her for the College's Honorary Fellowship. This is the highest honour that the College can bestow upon an individual, and only five are bestowed each year. Dr Brundtland is a worthy recipient of this honour.

Dr Gro Harlem Brundtland was born in Oslo, Norway. When she was 10, her family moved to the US where her father, who was a doctor, had been awarded a Rockefeller scholarship. A few years later the family moved again, this time to Egypt where her father was serving as a United Nations expert on rehabilitation. It seems that the seeds of her future careers were sown within these early years. The first to sprout was the seed of her medical career, as she became a doctor and specialised in the field of rehabilitation herself. She became a Master of Public Health and spent 10 years as a physician and scientist in the Norwegian public health system.
The second seed was that of political activism and at the age of 7 she was enrolled as a member of the Norwegian Labour Movement in its children's section. She has been a member ever since, leading the Labour Party to election victory three times.

The third seed was that of internationalism and a passion for global affairs, and perhaps the striking feature of Gro Brundtland's professional life is the way that these three strands, which could have been quite separate, have been woven together.

Distinction came early. As a mother and a newly qualified doctor, Gro Harlem Brundtland won a scholarship to the Harvard School of Public Health. Here she worked alongside distinguished public health experts, and her vision of health extending beyond the confines of the medical world into environment issues and human development began to take shape.

She returned to Oslo and the Ministry of Health in 1965 where the next 9 years were busy and productive. At the Ministry she worked in the children's department of the National Hospital and Oslo City Hospital and became Director of Health Services for Oslo's school children. At the same time she was bringing up her own family, representing Norway in international conferences and working her way up through the Labour Party hierarchy.

In 1974 her already formidable contribution was acknowledged and she became Minister of Environment in Norway, seeing this as an opportunity to put into practice her growing conviction of the link between health and the environment.

During the 1970s she acquired international recognition in environmental circles and a political reputation at home. In 1981, at the age of 41, she was appointed Prime Minister for the first time. Gro Harlem Brundtland was the youngest person and the first woman ever to hold the office of Prime Minister in Norway. With two other periods as Prime Minister, from 1986-1989 and 1990-1996, Dr Brundtland was Head of Government for more than 10 years.

During this time her early interest in international affairs developed into a growing concern for issues of global significance. She established and chaired the World Commission on Environment and Development and it was the recommendations of this Commission that led to the famous Earth Summit - the United Nations Conference on Environment and Development (UNCED), held in Rio de Janeiro in 1992.

Dr Brundtland was elected to the post of Director-General of the WHO in 1998 by the World Health Assembly. Her acceptance speech illuminates her view of her new role and that of the organisation that she leads. She said: "What is our key mission? I see WHO's role as being the moral voice and the technical leader in improving health of the people of the world. Ready and able to give advice on the key issues that can unleash development and alleviate suffering. I see our purpose to be combating disease and illhealth - promoting sustainable and equitable health systems in all countries." Actions speak louder than words. As Director-General of WHO, Dr Brundtland's many skills as doctor, politician, activist and manager have come together and she has reorganised WHO to meet the needs of the new century. This was no mean task!

She has also demonstrated a particular interest in mental health. She dedicated 7 April 2001 as Mental Health Day and the WHO's World Health Report for 2001 is dedicated to Mental Health. In addition, she has made the prevention of smoking and the combating of tobacco dependence a major priority, aiming to have the first ever WHO Convention on Tobacco by 2003 . Her initiative in this respect has been welcomed by many governments despite opposition from tobacco companies.

In summary, Dr Brundtland's contribution to medicine and global health issues in general and mental health in particular, is outstanding. She is a medical colleague who, despite having attained the summits of political achievement and international recognition, has remained closely in touch with her deep roots in medicine and public health.

Mr President, ladies and gentlemen, I started by explaining that an Honorary Fellowship is the highest honour that the College can bestow. It is apparent to all of us that Gro Harlem Brundtland is eminently worthy of this honour. I believe that it is also an honour for the College to have such a distinguished Fellow, whose presence among us emphasises the importance of mental health as a global issue. It is therefore a great pleasure to present Dr Gro Brundtland to you as an Honorary Fellow of this College.

\section{Professor Eugene Paykel}

(introduced by Professor C. Katona)

Eugene Stern Paykel was born in Auckland, New Zealand in 1934. The Paykel name is a household word in New Zealand as it is the main manufacturer of domestic appliances. I am sure Gene could have been a great success in the family business. Fortunately for us though he entered Medical School at the University of Otago in 1952. By the time he graduated in medicine in 
1956 his academic distinction was already apparent by the award of the university's

Stuart Prize and Joseph Pullar scholarship.

Gene has been a UK citizen since 1966. His basic and higher training in psychiatry was at the Maudsley Hospital where his contemporaries included Loic Hemsi and Trevor Silverstone. He then spent 5 years at Yale University, 1966-1971, where he was Co-Director and later Director of the Depression Research Unit, working closely with Gerald Klerman and Myrna Weissman and carrying out groundbreaking research on the classification of depression and on the role of life events in its aetiology.

On his return to the UK Gene was appointed consultant and senior lecturer at St George's Hospital. In 1975 he was promoted to reader and in 1977 to a personal chair. He was appointed to succeed Sir Martin Roth as Professor of Psychiatry of the University of Cambridge in 1985. He has written or edited eight academic psychiatric texts and over 300 scientific papers. Much of his recent work has been on the biology of depression and on its treatment in both hospital and primary care settings. He is regarded as one of the leading world authorities both on depressive illness and on puerperal psychiatric disorders.

When I told Gene I was going to be presenting him for our Honorary Fellowship, he asked me not to say he was (and I quote) a "grumpy old bugger who when you worked with him was perpetually away somewhere else". Nothing could be further from the truth. He was and remains an inspiring teacher who was trainer and mentor to a clutch of future professors of psychiatry including Thomas Barnes, Ted Dinan and myself. He was also impressively always there - to the extent we juniors had our work cut out hiding our plans on how to manage his patients from him lest he interfered. I remember visiting him in hospital after he'd suffered a back injury shortly after I started working with him. He was flat in bed, in severe pain but with a foot high pile of papers and a dictaphone and in full work mode.

Gene is also a very distinguished journal editor. With George Winokur he founded Journal of Affective Disorders and grew it into a major and highly cited journal. He then went on to succeed Michael Shepherd as sole Editor-in-Chief of Psychological Medicine, which under his stewardship has increased its range while remaining near the top of the premier league of psychiatric journals.

Several organisations have gone before us in recognising Gene's exceptional distinction, particularly in psychopharmacology. He is the current President of Collegium Internationale Neuropsychopharmacologium (CINP), was a Founder Fellow, Academy of Medical Sciences and earlier this year was recipient of the European College of Neuropsychopharmacology (ECNP) Lilly award for clinical neuroscience.

Gene Paykel has made a major and sustained contribution to the life of our College at the very highest level. Among other things he was Chairman of the Scientific Advisory Committee of the Defeat Depression Campaign, of the Social and Community Psychiatry Section and of the Joint Committee on Higher Psychiatric Training. Between 1994 and 1996 he was Vice-President of the College.

I am proud to be able to Present Professor Eugene Paykel for the award of our College's highest accolade, the Honorary Fellowship. Few people have contributed as much to our College, and to psychiatry.

\section{Professor Roy Porter} (introduced by Dr D. Bhugra)

It will not be an exaggeration to say that Professor Roy Sidney Porter is the most distinguished and outstanding social and medical historian of his generation. Professor Porter graduated from Christ's College Cambridge with first class honours with distinctions in the history tripos. Two years later he was appointed Research Fellow of Christ's College, Cambridge. In 1972 he was appointed Fellow and Director of Studies in History, Churchill College, Cambridge. He was awarded his PhD from Cambridge in 1974 and in the same year was appointed Assistant Lecturer in European History. He was appointed Lecturer in European History in 1977 and the same year he was appointed Dean of Churchill College, Cambridge. In 1979 he was appointed Senior Lecturer at the Wellcome Institute for the History of Medicine, London. American universities queued to honour him and offer him visiting professorship and fellow status. In 1991 he was appointed Reader and in 1993 appointed Professor. He is currently Professor in the Social History of Medicine at the Wellcome Institute for the History of Medicine. He has been a Visiting Fellow at the University of California at Los Angeles, Stanford University and Princeton University. He was elected Fellow of the British Academy and the New York Academy and was given the Honorary Fellowship of the Royal College of Physicians. With Dr German Berrios he founded the journal History of Psychiatry, which is going from strength to strength.

He has authored, co-authored, edited or co-edited more than 100 books and 350 academic papers. Of these, mention must be made of Mind Forg'd Manacles, which was awarded the Leo Gezshey Prize of the American Historical Association. His volumes The Faber Book of Madness, The History of Bethlem, Cultures of Psychiatry, London: A Social History and Enlightenment have already become classics. The volume on enlightenment has already gone into a second edition and is now being made into a film. He has made significant contributions to our understanding of the social history of stigma, mental illness, psychiatric institutions and alienists.

His teaching skills keep the students undergraduate and postgraduate spellbound. As this is the Royal College of Psychiatrists' meeting it is time for a confession. When I had the privilege of sitting through his lectures on history of mental illness, history came alive. He has the ability of presenting findings and observations as a painter would on a canvas. He has made significant contributions to our understanding of the social history of medicine in general and psychiatry in particular. It is a great source of pleasure and pride for the profession to present Professor Roy Porter for the Honorary Fellowship of the Royal College of Psychiatrists.

\section{Winter Business Meeting}

4.30-5.00p.m. on 5 February 2002, to be held at the Royal College of Psychiatrists following the meeting of Council. Chaired by the President, Professor John Cox.

\section{Agenda}

(1) To approve the Minutes of the previous Winter Business Meeting held at the Royal College of Psychiatrists on 6 February 2001

\section{(2) Obituary}

(3) Election of Honorary Fellows

\section{Professor David A. Alexander}

Throughout his career as a clinical psychologist, Professor Alexander has always believed in the mutual value of collaborative work between psychologists and psychiatrists, and between psychologists and other medical disciplines. He has worked in the University of Aberdeen's Department of Mental Health since 1971, acquiring a personal Chair in 1994. It is difficult to overestimate his contribution to undergraduate education in psychiatry, and through the Aberdeen Postgraduate Training Scheme in Psychiatry he has also provided excellent clinical and research supervision, and acted as advocate for many young psychiatrists. In 1998, Professor Alexander spearheaded the 